\title{
Udfordringer i
}

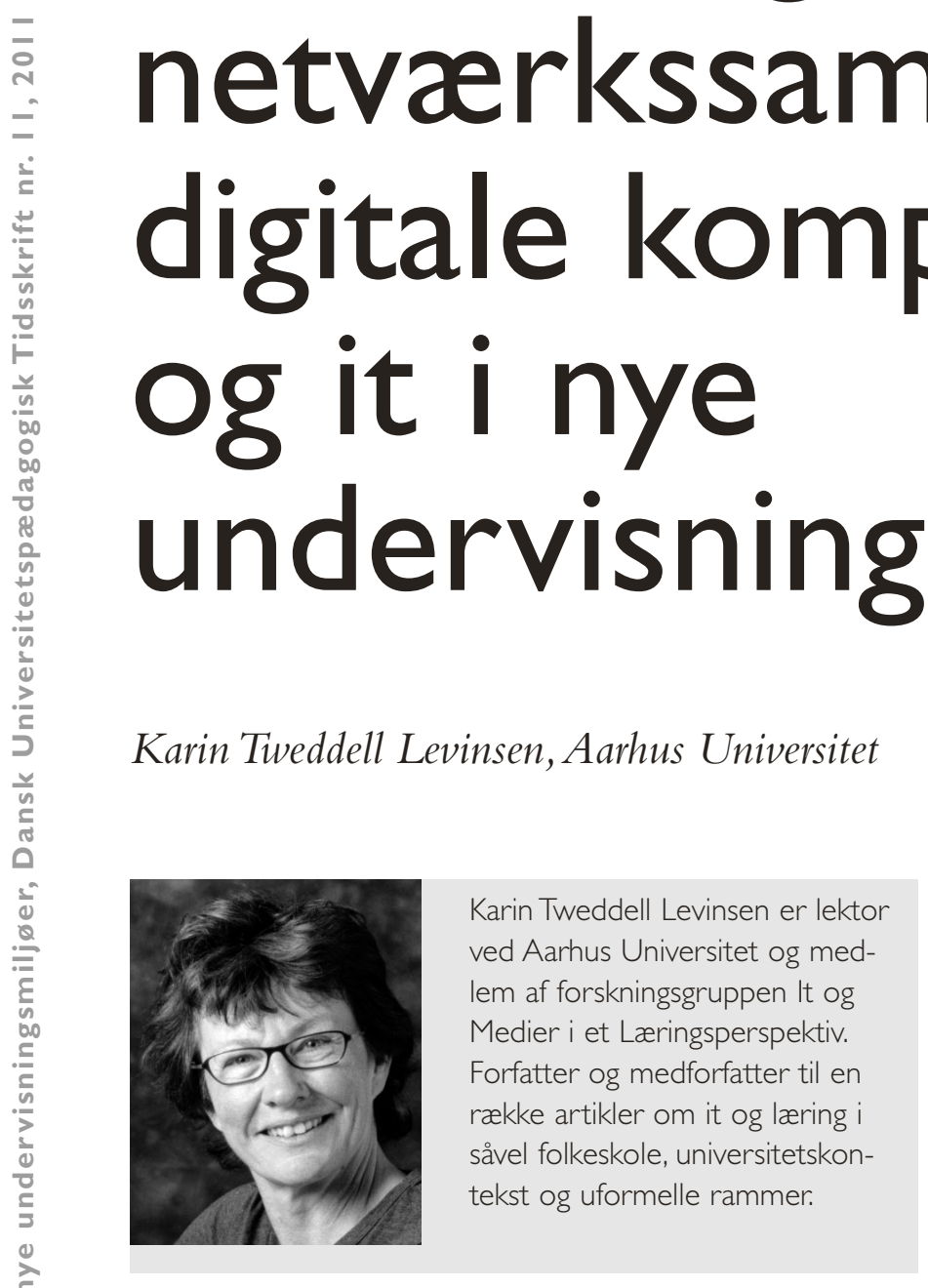

\section{Reviewet artikel}

Netvorksamfundet stiller krav til uddannelsessystemet om at favne en rekke kompetencer, der internationalt er defineret som nodvendige. Artiklen presenterer et casestudie der undersøger de didaktiske udfordringer i forbindelse med et autentisk undervisningsforlob på kandidatuddannelsen IT-Didaktisk Design. Casen udgøres af en konkret kompetenceudviklende praksis der er baseret på en (social) konstruktivistisk og materielt forankret padagogik. Pastanden er at der er behov for fanomenologisk at udforske kompetenceudvikling forståt som laceprocesser, for at kunne sige noget om hvordan didaktisk design kan støtte kompetenceudviklingen. Artiklen presenterer elementer af en sådan fanomenologi.

\section{Baggrund}

Netværksamfundet er karakteriseret af foranderlighed og en digitalt medieret globalisering, hvor it er usynligt og allestedsnærværende vævet ind i samfundet på alle niveauer (Castells, 2000). Kravet til borgerne er, at de kan forholde sig til og følge med forandringerne for at kunne agere $i$ et flydende og gennemdigitaliseret sam-

fund. Castells opdeler arbejdskraften i de selvprogrammerende, der evner selvinitieret livslang læring, mens de generiske har behov for efteruddannelse. Castells argumenterer, at samfund med selvprogrammerende arbejdskraft vil klare sig i den globale konkurrence og at uddannelsessystemet derfor må prioritere denne opgave. Teorien fik, sammen med begreberne Livslang Læring og Digital Kompetence (Tyner, 1998; Jewett \& Kress, 2003; Katz, 2005; Bawden, 2008), betydning for definitionen af netværksamfundets nøglekompetencer, der bruges som grundlag for regeringsbeslutninger (OECD, 2001; European Commission, 2003; Rychen \& Salganik, 2003; Martin, 2005; G8, 2006). Udfordringen er imidlertid, hvordan projektet gribes an i praksis.

Forskningen viser, at der kan opstå synergi mellem it, læring og digitale kompetencer og nøglekompetencer og at relationerne ikke er deterministiske (Sørensen, Audon \& Levinsen, 2010; Gynther, 2010). Forskningen viser også, at evnen til at forholde sig til foranderlighed og kompleksitet ikke er iboende (Sørensen, 1999; Buckingham, 2003; Malyn-Smith, 2004; Breivik, 2005; Levinsen \& Sørensen, 2008). På basis af forskning i unges (Sørensen, 1999; Oblinger, 2003; MalynSmith, 2004; Dede, 2005; Oblinger \& Oblinger, 2005) og voksnes (Levinsen, 2008) møder med it ved vi en del om, hvad der karakteriserer selvprogrammerende aktører: De undrer sig og stiller spørgsmål; eksperimenterer og udforsker for at knække koden; finder det naturligt at videndele og praktisere netværk; overfører potentialer mellem kontekster; er kreative; besidder et bredt repertoire af udforskningsstrategier; er stærkt indre motiveret for at overvinde udfordringer.

På trods af denne viden ses en tendens til teknologideterminisme hos beslutningstagere, der foretrækker 
at fortolke begreberne som produktorienterede lister, sådan som de er formuleret i OECD's program Definition and Selection of Competencies (DeSeCo) (Rychen \& Salganik, 2003) og i Danmark som det Nationale Kompetenceregnskabs 10 nøglekompetencer (UVM, 2003). I takt hermed fremstilles kompetencetilegnelse som "noget der sker af sig selv« og kobles ureflekteret sammen med brug af it. Et aktuelt eksempel er Det Digitale Råds rapport om fremtidens skole (2010). Ny forskning viser, at det ikke forholder sig sådan. Trods massiv investering $\mathrm{i}$ hardware er it ikke integreret som forventet i folkeskolen (Levinsen \& Sørensen, 2008; EVA, 2009; Gynther, 2010), og denne forskning argumenterer for nye didaktiske former, hvor digitale kompetencer og nøglekompetencer ses integreret i en nutidig ramme. Begrebet Digital Kompetence er blevet for snævert og i stedet foreslås Martins begreb Digital Dannelse (2006), der har ligheder til Castells begreb Selvprogrammering. Digital dannelse defineres som tre grader af engagement og læring: 1) digital competence, at kunne betjene it;2) Digital uses, et udviklet repertoire af måder at omgås it på; 3) digital transformation, hvor individet magter radikal innovation i omgangen med it. Fra dette perspektiv stilles spørgsmål, som er den teknologideterministiske position fremmed:

$\$$ Hvordan bliver voksne, der ikke er født ind i digitaliseringen, selvprogrammerende, hvis de ikke er det allerede?

$\int$ Hvordan sikrer vi, at nye generationer af digitale indfødte vokser op til at være selvprogrammerende?

Spørgsmålene synliggør manglen på viden om, hvordan mennesker kommer til at magte selvinitieret, livslang læring, og hvorledes disse processer væver sig sammen med digitaliseringen. Med andre ord er der behov for at udforske læreprocesserne fænomenologisk. Artiklen præsenterer et casestudie af et konkret didaktisk forløb, der søger at identificere elementer til en sådan fænomenologi.

\section{Casen}

Casen tager afsæt i modulet Teknologirelateret Workshop på kandidatuddannelsen It-didaktisk Design (For detaljer se ITDD, 2011) i efteråret 2009. Grundet teknologiinddragelse er ITDD akkrediteret til forhøjet STÅ og hold på max 20. ITDD var ny i 2009 og første årgang havde 8 studerende, hvorfor modulet havde blot tre deltagere. Modulet består af tre workshops (herefter WS) baseret på problemorienteret projektpædagogik og teorigenererende praksis. Underviserens rolle er at facilitere gennem åben dialog, der også sikrer, at praksis forankres i teorien. Hver WS varer 4 uger og tilbyder 4 sessioner á 6 timer. Casen bygger på session $1 \mathrm{i}$ WS I.

WS 1 er designet til at udvikle selvprogrammering og digital dannelse ved at udfordre deltagernes strate- gier og gøre dem synlige som objekter for refleksion og læring. I session 1 sker dette som følger: Deltagerne befinder sig i hele forløbet sammen i undervisningslokalet, således at de kan vælge at arbejde individuelt og sammen. Her introduceres de til en teoretisk værktøjskasse via udvalgt litteratur og et kort oplæg.Værktøjskassen bruges til individuel, skriftlig vurdering af egen selvprogrammeringskompetence, og forskningsmæssigt er den et redskab til indsamling af empiri ud fra et førstepersonsperspektiv, da deltagerne selv producerer både data og analyse.Værktøjskassen beskrives i næste afsnit. Efterfølgende konfronteres de med noget ukendt, som de udforsker med henblik på at afdække didaktiske potentialer. Undervejs skriver de løbende individuelle notater med fokus på selvprogrammering:

$\$$ Hvordan agerer jeg når jeg skal udforske?

$\int$ I hvilke situationer foretrækker jeg at arbejde alene/ med andre?

\Oplever jeg forhindringer/udfordringer og hvordan handler jeg?

$\$$ Hvad hjælper mig til at komme videre?

$\$$ Ændrer jeg strategi i løbet af dagen?

Til slut nedskrives dagens umiddelbare indtryk. Modulets summative evaluering er et 3-4 siders individuelt refleksionspapir over hele WS I forløbet. Aktiviteterne i session 1 videodokumenteres og streames (stationært kamera til total og håndholdt til closeups). Optagelserne uploades sammen med deltagernes skriftlige produktion til et fælles onlinerum. Herved sikres deltagerne et refleksionsmateriale, samtidig med at materialet udgør casens empiri. Optagelser fra det stationære kamera dokumenterer forskeren som aktør på lige fod med de studerende, hvilket sikrer, at forskerens interventioner efterfølgende kan vurderes, idet validiteten af de studerendes førstepersonsperspektiv afhænger af, at forskeren ikke intervenerer ledende men alene med åbne interventioner. Der blev ikke identificeret ledende interventioner.

En væsentlig ingrediens i WS I designet er "noget teknologisk og digitaliseret ukendt", som skal være udfordrende men ikke må ligge udenfor deltagernes forudsætninger. Den valgte teknologi spiller flere roller i designet. I det individuelle læringsrum er tanken, at teknologien faciliterer indre dialog $i$ en cyklus af internalisering af noget $\mathrm{i}$ omverden og eksternalisering af noget i den enkeltes bevidsthed. I det kollaborative læringsrum er tanken, at deltagerne materialiserer konstruktioner, der repræsenterer både verbaliserbare forestillinger, uudsigelige ideer og tavs viden (Polanyi, 1968; Levinsen \& Nielsen, 2011). Materialiseringerne kan fungere som grænseobjekt, der muliggør videndeling (Wenger, 2000). De forstås således som bærere af et nonverbalt og multimodalt sprog, der støtter en fælles meningsforhandling og (re)arrangering af materialiteten. 


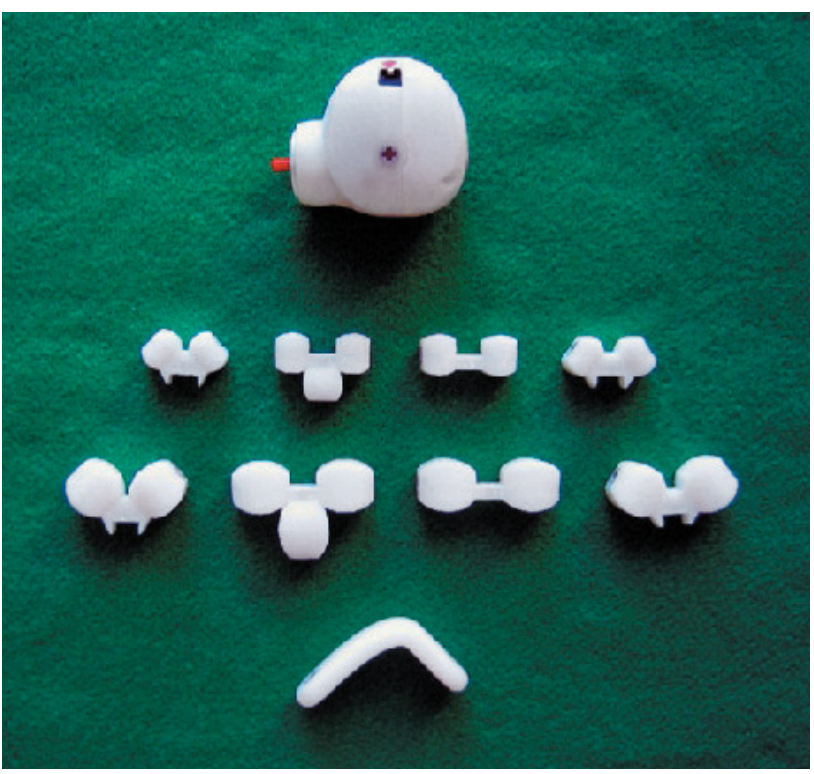

Figur 1: Elementer og et dyr bygget med Topobo

I 2009 var det ukendte repræsenteret ved prototypen Topobo, verdens første konstruktionslegetøj med kinæstetisk hukommelse. Topobo består af passive og aktive dele, der klikkes sammen (figur 1). Den kinæstetiske hukommelse husker de bevægelser, man udfører ved at manipulere de aktive dele. En særlig del - dronningen - kontrollerer netværk af aktive dele og muliggør komplekse bevægelsesmønstre. Man programmerer så at sige Topobo gennem fysisk manipulation af materialiteten. Når en bevægelse er registreret, kan man observere, hvordan den samlede konstruktion bevæger sig og eksperimentere med konstruktion og bevægelser.

\section{Teoretisk værktøjskasse - at gøre læring synlig}

Læring er individuel og utilgængelig for direkte observation og intervention. Til WS I er udviklet en teoretisk værktøjskasse med to formål: 1) Gøre læring umiddelbart synlig som objekt for selvrefleksion og meningsforhandling. 2) Stilladsere fortsat 2. ordens iagttagelse og refleksion.Værktøjskassen er konstrueret ud fra Castells teori om netværkssamfundet (2000), Rogers' Dif-



fusion of Innovation Theory (1985) og Dreyfus \& Dreyfus' kompetencemodel (1988). Teorierne belyser forskellige dimensioner af selvprogrammering og digital dannelse og deres kategorier omsættes i værktøjet til graduerede skalaer, som deltagerne bruger til selvevaluering.

Castells typer, selvprogrammerende og generisk individ (beskrevet $\mathrm{i}$ indledningen), tilbyder et redskab til refleksion over, hvor den enkelte ser sig selv på skalaen fra uformelt personligt initiativ til behov for formaliserede læringsrammer.

Rogers beskriver hvordan, hvorfor og med hvilken hastighed, innovationer optages i store populationer, som inddeles i fem kategorier (figur 2). Innovators udforsker alt nyt. Early Adopters afventer Innovators og optager dét der forekommer lovende. Disse grupper beskrives som individer med stærk indre motivation. Early Majority optager det nye, hvis det bliver populært blandt Early Adopters, hvorefter det betragtes som mainstream. Late Majority optager nyt når de er nødt til det. Disse to grupper har behov for tilvænning og formål. For Early Majority kan formålet være at udforske et givet potentiale, mens det for Late Majority er, om »det kan betale sig«. Laggards vil gå langt $\mathrm{i}$ bestræbelserne for at undgå forandring. Ifølge

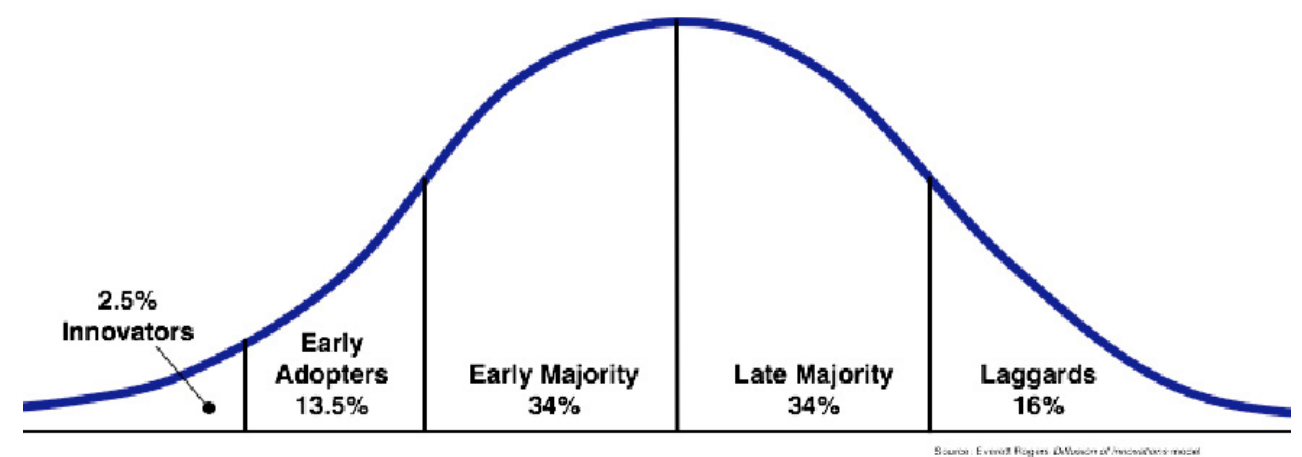

Figur 2: Rogers' Diffusion of Innovation Curve (efter Rogers 1995) 
Rogers kan man flytte sig mellem kategorierne. Diffusionshastigheden er desuden afhængig af, hvor radikale forandringer en optagelse vil medføre.

Rogers teori tilbyder en beskrivelse af holdninger og reaktioner ved konfrontation med innovationer. Teorien kan derfor fungere som redskab for selvvurdering af graden af indre motivation på skalaen fra Innovator til Laggard.

Dreyfus \& Dreyfus bygger deres teori om kompetencemæssig progression på observation af skakspillere og sygeplejerskers måder at håndtere kompleksitet på i praksis. Med Piagets læringsteori som teoriramme har de formuleret en femtrins Model of Skill Acquisition, hvor trinene fænomenologisk beskriver de tilhørende læringsstrategier i progressionen: 1) Novicen udøver kontekstuafhængig og ureflekteret trial-and-error. 2) Den Avancerede Begynder er afhængig af regler og reflekterer kontekstuafhængigt indenfor learning-bydoing strategier. 3) Den Kompetente forholder sig til kontekst, handler uafhængigt og kan planlægge og ændre strategi, men er ukritisk overfor udgangspunkt og grundantagelser. Disse trin er - i forskellig grad afhængig af regler og instruktion. Trin 4) Dygtig, udfordrer grundlæggende antagelser med kritisk refleksion, og 5) Eksperten møder udfordringer intuitivt med et repertoire af erfaringsbaseret tavs viden (Polanyi, 1968). Begge trin behersker Reflection in Action (Schön, 1983) og akkommoderer på radikale måder. Dreyfus \& Dreyfus' model tilbyder et redskab til selvvurdering af, hvor avancerede den enkelte finder sine personlige strategier på skalaen fra Novice til Ekspert.

\section{At gøre selvprogrammering - de studerendes forsteperson perspektiv}

I dette afsnit præsenteres forskerens kondensat af deltagernes førstepersonsperspektiv, egen analyse og refleksion over læring, som de fremstår i deres skriftlige bidrag.

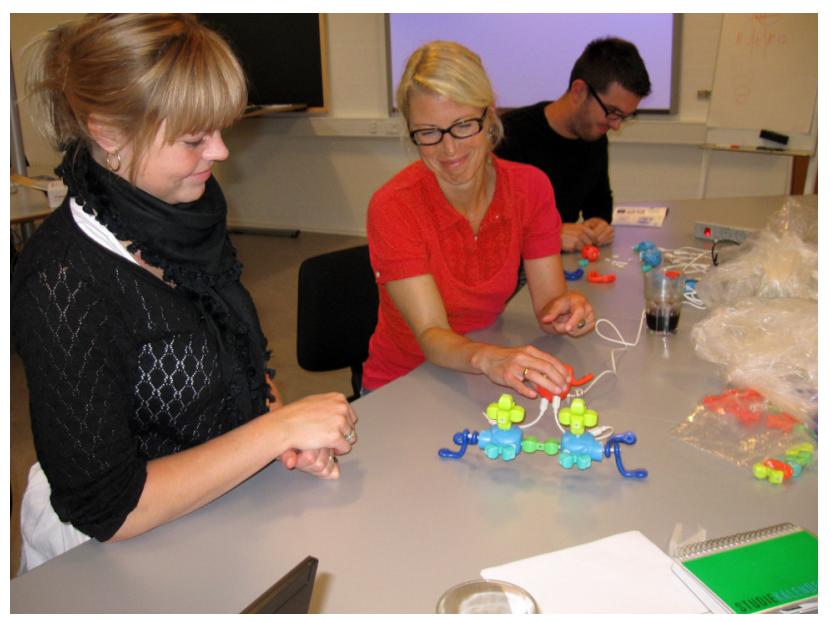

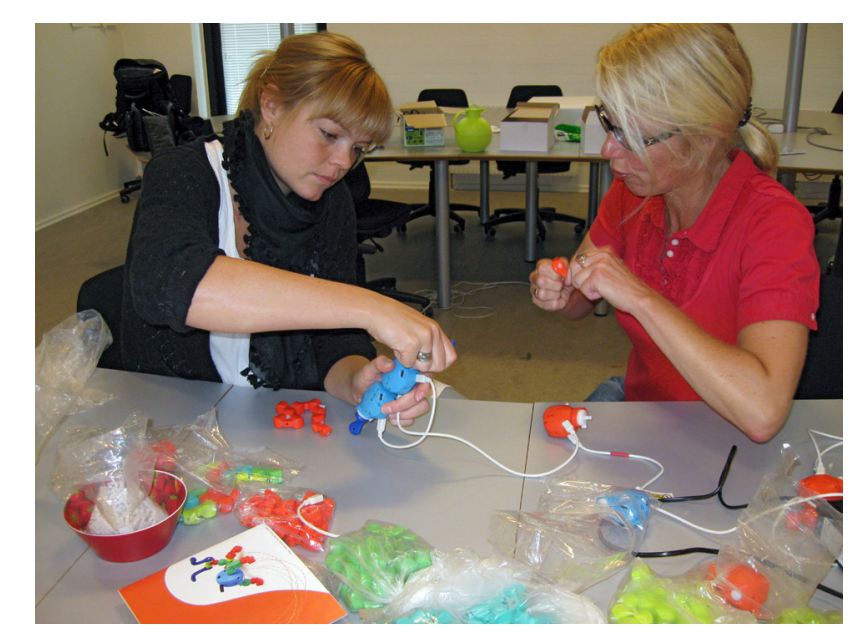

A

33-årig kvinde, folkeskolelærer, skriver lærebøger i visuel kultur og billedkunst. A vurderede sig selv som Early Adopter og Kompetent selvprogrammerende. I ePortfolien beskriver A sin overraskelse over, at hun efterligner de andre og fingererer tilfældigt $i$ en trial-anderror strategi, hvor hun havde forventet at reflektere over erfaringer og stille udforskende spørgsmål. A erfarer her, at hun agerede generisk som Early Majority og Novice. I refleksionspapiret skriver A: jeg var åben overfor det nye men gik alligevel til det på en formaliseret måde. Jeg havde ikke nogen forventning om at kunne fä noget til at fungere. A opdager, at det svære for hende er frustrationen over, at hun ikke umiddelbart gennemskuer Topobo. På session 2 har A besluttet at bruge sin nyvundne indsigt og aktivt udfordre sin selvprogrammeringskompetence ved at udvikle et læringsobjekt i Google Maps, som hun ingen erfaringer har med. Hun eksperimenterer med at udforske og formulere undringsspørgsmål i håb om at opleve udfordringer frem for forhindringer og beskriver at dette lykkes for hende. A formulerer også et behov for at stille sig selv meningsfulde og konkrete opgaver for at kunne motivere sig. Desuden bliver det vigtigt for hende at insistere på individuel arbejdsro ved siden af det distribuerede rum.

\section{B}

45-årig kvinde og specialunderviser der introducerer digital støtte til voksne ordblinde og hjælper dem med at implementere støtten. B vurderer sig selv som Late Majority og Novice og finder i sine refleksioner at dette er korrekt, fordi hun kan se på videoen, at hun ikke tager initiativer. B opdager imidlertid, at hendes verbale forslag driver den fælles læring om Topobo fremad. Fx forstår hun som den første forskellen mellem de aktive dele og dronningen ved alene at iagttage de andres manipulationer. Idet B refererer til videoen, skriver hun: Underviseren kommenterer mit forslag, og at min tilgang ser ud til at vere intellektuel - det er slet ikke sådan jeg ser mig selv! Men elementerne lod som en elektro-

Figur 3:To trin i bygningen af den vandrende krabbe 
motor, og de forskellige farver så ud til at opfore sig forskelligt. De mindede mig om serielle og parallelle elektriske kredslob, som jeg havde $i$ skolen. Jeg forstod aldrig dengang, hvad de kredsløb gik ud på. Til sin overraskelse opdager B, at hun er en god observatør der reflekterer og bidrager konstruktivt til den fælles strategi, svarende til trinene Kompetent til Dygtig. I den konkrete situation provokerer underviserens kommentar B til at udvide sin strategi til også at omfatte fysisk manipulation. Snart bygger hun sammen med A en krabbe og opfinder små eksperimenter, der systematisk udforsker sammenhængen mellem tyngdekraft og bevægelse.

$\mathrm{B}$ understreger at hun klart foretrækker samarbejde. Hun skriver i sit refleksionspapir, at den nye indsigt $i$ egne strategier kan hjælpe hende til bedre at forstå de ordblinde voksnes situation og deres reaktioner $i$ forhold til den for dem ukendte digitale støtte.

\section{C}

26-årig mand, folkeskolelærer og pædagogisk itvejleder ved et CVU. Han beskriver sig selv som en, der kan lide at fingerere og undersøge nye »dimser». C forventede at være selvprogrammerende på trin 4 samt Innovator. I praksis erfarede han at gå i stå med Topobo i en endeløs række af trial-and-error uden fremskridt. I refleksionspapiret nævner han B's tolkning af forskellen mellem aktive dele og dronninger som et personligt vendepunkt, der inspirerede ham til at udvide sin strategi:... jeg begyndte at overlade pilleriet til de andre og $i$ stedet foresla nye måder og losninger. Jeg fandt ud af, at det var nemmere at reflektere og modificere mine forståelser, når jeg ikke altid placerede mig selv i forste rakke som den, der piller med tingene. Ved gennemsyn af videoen opdagede han, at han fysisk tager ting ud af A's hænder. I ePortfolien reflekterer han over, hvordan trangen til at pille bliver en barriere både for ham selv og for andre. I løbet af WS I beslutter C at øve sig $\mathrm{i}$ at blande fingerering med refleksion. Også C konstaterer, at han har behov for både individuelt rum og videndeling. Han forestiller sig, at den nye indsigt kan blive vigtig $i$ hans professionelle virke som pædagogisk it-vejleder.

\section{Diskussion}

Udfordringen er nu, om de to spørgsmål, der blev rejst $\mathrm{i}$ indledningen, er blevet belyst med casen.

1. Hvordan bliver voksne, der ikke er født ind i digitaliseringen, selvprogrammerende, hvis de ikke er det allerede?

2. Hvordan sikrer vi, at nye generationer af digitale indfødte vokser op til at være selvprogrammerende?

WS 1 var designet til at udvikle selvprogrammering og digital dannelse ved at udfordre deltagernes udforsknings- og handlestrategier og gøre dem synlige som objekter for refleksion og læring. Dermed relaterer casen direkte til det første spørgsmål, der delvis kan belyses ud fra, om der kan findes sammenhænge mellem designet af WS I og læring hos deltagerne. Spørgsmål to berøres derimod kun indirekte.

I de skriftlige indlæg peger deltagerne på, at de oplevede vendepunkter i deres opmærksomhed på, hvordan de agerede. De beskriver, hvordan denne opmærksomhed fik konsekvenser ikke blot i session 1, men at den antog en mere permanent karakter, der gjorde det muligt for dem fortsat bevidst at udfordre deres strategier. To umiddelbare erfaringer blev synlige for dem gennem forløbet. De var i udgangspunktet ikke bevidste om: 1) deres egne strategier;2) at strategierne kun fungerede til en vis grænse, hvorefter de blev til barrierer. Det teoretiske værktøj og kravet om at skrive løbende notater med et defineret fokus fungerede som intenderet $\mathrm{i}$ WS I designet. Processerne blev synlige og dermed genstand for refleksion. For deltagerne betød det, at de i løbet af session 1 bevidst valgte at ændre strategi men også, at opmærksomheden mod strategierne efterfølgende indgik i deres aktive repertoire. Her er tale om en læring, der kan beskrives med Piagets begreb akkommodation, altså en radikal forandring hos den enkelte. Det interessante er, at deltagerne ikke udskifter deres strategier men derimod udvider dem ved at optage strategielementer fra hinanden. De benytter det teoretiske værktøj til at beskrive, hvordan de bevæger sig fra Novice hen mod Dreyfus \& Dreyfus' 4 trin: Dygtig. I Martins teori om digital dannelse (2006) svarer det til, at man opbygger et repertoire af handlestrategier af digital uses i mødet med det ukendte. Deltagerne diskuterer begrebet meningsfuld som drivkraft til at motivere selvudfordring og har forskellige udlægninger af, hvad det vil sige, at noget er meningsfuldt. For A er det at kunne se det ukendte i forhold til egne interesser; for $\mathrm{B}$ er det nødvendighed; for $\mathrm{C}$ er alt nyt meningsfuldt, fordi det er ukendt. For didaktisk design af kompetenceudvikling er dette vigtigt, fordi den udbredte tilgang er en »one-size-fitt's-all«-didaktik, der netop af disse årsager kan vise sig at være helt utilstrækkelig. Også voksne har behov for differentiering.

Fænomenologisk kan læringsprocessen beskrives som bevægelser, der repræsenterer progression i fire dimensioner:

1) Strategi: En bevægelse fra enstrengede - til flerstrengede strategier;

2) Kompleksitetshåndtering: En bevægelse hen mod at kunne magte stadig større grader af kompleksitet;

3) Refleksivitet: En bevægelse fra ureflekteret trial-anderror til erfaringsbaseret og kontekstualiseret refleksion;

4) Kropsforankring: En bevægelse fra ikke at være opmærksom, over at være bevidst om at være opmærk- 
som, til at opmærksomhed på strategierne bliver en del af et reflection-in-action-repertoire.

Den forskningsmæssige synliggørelse af disse bevægelser i dimensionerne gør det muligt at hævde, at de processuelle greb i didaktisk design af kompetenceopbygning af selvprogrammering og digital dannelse bør defineres ud fra dimensionerne og iagttages ud fra bevægelserne og ikke ud fra de tidligere omtalte officielle præskriptive lister over fremtidens kompetencer. Argumentet er, at hvis den lærende har progression på de fire dimensioner - strategi, kompleksitetshåndtering, refleksivitet og kropsforankring - og gradvis lykkes med at internalisere dem (læring som proces), vil læringen bl.a. udmønte sig $\mathrm{i}$, at individet behersker de præskriptive punkter i de officielle lister (læring som produkt).

Formmæssigt fremtræder læreprocessen fænomenologisk som en vekselvirkning mellem individuel koncentration, kollektiv videndeling og sidemandsoplæring. Både $\mathrm{A}$ og $\mathrm{B}$ erfarer i forløbet, at det individuelle rum har stor betydning for deres læring. Det gælder både læring om Topobo og udvikling af egne kompetencer. Dette er en væsentlig erkendelse i forhold til didaktisk design af kompetenceudvikling i netværkssamfundet, da det dominerende socialkonstruktivistiske paradigme favoriserer kollaboration og social læring på bekostning af det individuelle læringsrum. Disse iagttagelser understreger væsentlige didaktiske overvejelser og viser samtidig, at det er muligt at integrere konkret faglig læring med en langsigtet konsolidering af netværksamfundets kompetencer. Denne iagttagelse siger noget grundlæggende $\mathrm{i}$ forhold til det andet spørgsmål, nemlig uddannelse af fremtidige generationer. Didaktiske design, der integrerer progression på de fire dimensioner $i$ det faglige arbejde med konkrete fagligheder, er en del af nøglen til at imødegå denne udfordring.

I forhold til det første spørgsmål, der retter sig mod voksnes kompetenceudvikling, peger casestudiet på betydningen af at fremhæve dimensionen vedr. opmærksomhed mod egne strategier og synliggørelsen af dem, som objekt for refleksion og læring. I forhold til det andet spørgsmål om at sikre at fremtidige generationer uddannes til selvprogrammering, peger casestudiet på, at den didaktiske designer i sin orkestrering af dimensionerne bør sikre, at de fire dimensioner integreres i de måder, hvorpå de lærende arbejder med det konkrete faglige indhold.

\section{Referencer}

Bawden, D. (2008). "Origins and concepts of digital literacy«, I: Lankshear \& Knobel (Red.) Digital Literacies: Concepts, Policies and Paradoxes, New York: Peter Lang, 15-32.

Breivik, P. S. (2005. "21st century learning and information literacy«, Change 37 (2), 20-27.

Buckingham, D. (2003). Media Education: Literacy, Learning and Contemporary Culture. Cambridge: Polity Press.
Castells, M. (2000). "Materials for an exploratory theory of the network society", British Journal of Sociology 51 (1), 5-24.

Dede, C. (2005). »Planning for Neo-Millennial Learning Styles«, Educause Quarterly 1, 7-12.

Det Digitale Råd (2010). Den digitale skole - en business case for fremtiden. 2. rapport fra Det Digitale Råd, maj 2010, Udgivet af: Det Digitale Råd /v. CEDI.

Dreyfus, H.L. \& Dreyfus, S. (1988). Mind over Machine: The Power of Human Intuition and Expertise in the Era of the Computer. N. Y: Simon and Schuster.

European Commission (2003). eLearning: Better eLearning for Europe, Directorate-General for Education and Culture. Luxembourg Office for Official Publications of the European Communities.

EVA (2009). It i skolen - rapport, (C2009 Danmarks Evalueringsinstitut.

G8 (2006). G8 World Summit in St.Petersburg, July 16, 2006.

Gynther, K. (2010). Didaktik 2.0, København: Akademisk Forlag.

ITDD (2011). Undervisningsplan, tilgået 18. marts 2011. http:// www.dpu.dk/uddannelse/kandidatuddannelser/oversigtoveruddannelser/itdidaktiskdesign/

Jewett, C. \& Kress, G. (2003). Multimodal Literacy, New York: Peter Lang.

Katz, I. R. (2005). Beyond technical competence: Literacy in information and communication technology. Educational Technology Magazine 45 (6), 44-47.

Levinsen, K. (2008). „Neomillenial Learning Styles og Mønsterbrydere«. I Andreassen, Meyer \& Ratleff (red.) Digitale Medier og didaktisk design, Danmarks Pædagogiske Universitets Forlag. 192-211.

Levinsen, K. and Sørensen, B. H. (2008). It, faglig laring og paedagogisk videnledelse, forskningsrapport, DPU, tilgået 18. marts 2011. pure. au.dk/portal/files/210/Rapport_PIL_2008.pdf

Levinsen, K. \& Nielsen, J. (2011). »Innovating Design for Learning in the Networked Society", i Dirckinck-Holmfeld, Hodgson \& McConnell (Eds) Exploring the Theory, Pedagogy and Practice of Networked Learning, To be published by Springer, NY, 2011.

Martin, A. (2005). DigEuLit - a European Framework for Digital Literacy: a Progress Report. Journal of eLiteracy 2, 130-136.

Martin, A. (2006). "A European framework for digital literacy«, Digital Kompetanse 2, 151-161.

Malyn-Smith, J. (2004). "Power Users of Technology - Who are they? Where are they going? Why does it matter? «. UN Chronicle 2, 58-61

Oblinger, D. (2003). »Boomers, Gen-Exers and Millennials: Understanding the New Students", EDUCAUSE 38, 36-43.

Oblinger, D. \& Oblinger, J. eds. (2005). "Educating the Net Generation «, EDUCAUSE e-book, tilgået 18. marts 2011. www. educause.edu/educatingthenetgen/

OECD (2001). Meeting of the OECD education ministers, Paris, 3-4 April 2001, tilgået 18. marts 2011. http://www.oecd.org/dataoecd/40/8/1924078.pdf

Polanyi, M. (1968). "Logic and Psychology «, Journal of the American Psychological Association 23, 27-43.

Rogers, E.M. (1995). Diffusion of innovations (4th ed.). New York: The Free Press.

Rychen, D. and Salganik, L. (2003). Key Competencies for a Successful Life and Well-Functioning Society. Hogrefe \& Huber, Cambridge MA.

Schön, D. (1983). The Reflective Practitioner: How Professionals Think in Action. London: Temple Smith.

Sørensen, B.H. (1999). Projektarbejde fra begyndertrinnet - medier og formidling, København: Danmarks Lærerhøjskole.

Sørensen, B. H., Audon, L. \& Levinsen, K. (2010). Skole 2.0, KLIM.

Tyner, K. (1998). Literacy in a Digital World, Mahwah, NJ: Erlbaum.

UVM (2003). Noglekompetencer - forskerbidrag til Det Nationale Kompetenceregnskab, tilgået 18. marts 2011. http://pub.uvm. $\mathrm{dk} / 2002 / \mathrm{nkr} /$ dokumentationsrapport/bilag.html

Wenger, E. (2000). »Communities of Practice and Social Learning Systems«, Organization, 7(2). 225-246. 